DOI: $10.19195 / 0524-4544.321 .13$

\author{
MARTA JANKOWSKA \\ Uniwersytet Wrocławski \\ marta.jankowska@uwr.edu.pl
}

\title{
Administracyjnoprawne aspekty zmian powtarzających się nazw ulic Wrocławia po II wojnie światowej
}

\section{Zagadnienia ogólne}

Administracyjnoprawna regulacja dotycząca określania ulic jest zagadnieniem wielowymiarowym. Oprócz nazewnictwa trzeba wyróżnić także problematykę geodezyjną, topograficzną czy też aspekt numeracji nieruchomości. Jednak nazewnictwo ulic jest najbardziej wrażliwe na przemiany historyczne, społeczne czy topograficzne. W rezultacie zmian nazwa ulicy staje się swoistym świadectwem historii. Badając nazewnictwo, należy uwzględniać wszystkie konteksty i pobudki, w efekcie których nazwa ulicy zyskała określone brzmienie, jednocześnie nie zapominając o jej pierwotnym użytkowym przeznaczeniu, jakim jest określenie miejsca zamieszkania.

Zagadnienie nazewnictwa ulic we Wrocławiu nie zostało szczegółowo omówione $\mathrm{w}$ literaturze. Istnieją głównie publikacje objaśniające znaczenie samych nazw, a więc skupiające się na onomastyce. Nazwy ulic w niemieckim jeszcze Wrocławiu omawia dzieło Hermanna Markgrafa ${ }^{1}$ ze schyłku XIX w. Duże znaczenie w tym zakresie ma także książka Adolfa Weissa ${ }^{2}$ z początku XX w. Po 1945 r. najważniejszą, uzupełniającą dzieło Markgrafa o współczesne dane, pozycją jest książka Zygmunta Antkowiaka ${ }^{3}$. Pewne informacje zawierają także wrocławskie

${ }^{1}$ H. Markgraf, Die Straßen Breslaus, Breslau 1896.

2 A. Weiss, Wie Breslau wurde, Breslau 1907.

3 Z. Antkowiak, Ulice i place Wrocławia, Wrocław-Warszawa-Kraków 1970. 
leksykony Zygmunta Antkowiaka ${ }^{4}$ (2 wydania) i Gerharda Scheuermanna ${ }^{5}$ oraz encyklopedia ${ }^{6}$ Jana Harasimowicza i Włodzimierza Sulei (3 wydania). Należy też wyróżnić literaturę omawiającą nazwy tych ulic wrocławskich, których nazwy stanowią imiona i nazwiska patronów. Nad tym zagadnieniem pochylili się Zygmunt Antkowiak ${ }^{7}$ oraz Ewa Kobel ${ }^{8}$. Nie można zatakże pomnieć o niemiecko-polskim spisie wszystkich ulic, placów oraz mostów Wrocławia autorstwa Tomasza Kruszewskiego ${ }^{9}$. Autor ten poruszył także dwa problemy szczegółowe w artykułach naukowych ${ }^{10}$. Próbą kompleksowej i wielopłaszczyznowej syntezy zmiany nazewnictwa wrocławskich ulic jest pozycja Kamili Kędziory ${ }^{11}$. Książka ta dzieli przyjęte w niej ramy czasowe na podokresy, które bezpośrednio wynikają z zachodzących przemian historycznych mających wpływ na nazewnictwo, a następnie poddaje każdy z nich wnikliwej analizie. Techniczne wyodrębnienie zmian w nazewnictwie nie jest jednak pozbawione emocjonalnego nacechowania. Autorka zaznaczyła, że nazewnictwo jest każdorazowo nośnikiem głębszego przekazu, a nie tylko formą użytkową.

Powstały także mniej obszerne publikacje, które nie są bez znaczenia dla poruszanej problematyki. Były one drukowane w periodykach, m.in. w „Kalendarzu Wrocławskim". Należą do nich artykuły Andrzeja Jochelsona ${ }^{12}$, artykuł Bogdana Sicińskiego ${ }^{13}$, artykuł Zbigniewa Magdziarza ${ }^{14}$ oraz wiele artykułów Bernarda Jancewicza ${ }^{15}$.

${ }^{4}$ Z. Antkowiak, Wrocław od A do Z, Wrocław-Warszawa-Kraków, wyd. 1. 1991 i wyd. 2. 1997.

5 G. Scheuermann, Das Breslau Lexikon, t. I. A-L, t. II. M-Z, Dülmen 1994.

${ }^{6}$ Encyklopedia Wrocławia, red. J. Harasimowicz, W. Suleja, Wrocław 2006.

7 Z. Antkowiak, Patroni ulic Wrocławia, Wrocław 1982.

8 E. Kobel, Patroni wrocławskich ulic, placów i zaułków, Wrocław 2008.

9 T. Kruszewski, Niemiecko-polski spis ulic, placów i mostów Wrocławia 1873-1997, Wrocław 1997. Prof. dr hab. Tomasz Kruszewski, kierownik Zakładu Historii Administracji w Instytucie Historii Państwa i Prawa na Wydziale Prawa, Administracji i Ekonomii Uniwersytetu Wrocławskiego; członek Komisji Nazewnictwa Ulic przy Towarzystwie Miłośników Wrocławia, aktywista Towarzystwa Opieki nad Zabytkami we Wrocławiu, w którym jest członkiem Komisji Rewizyjnej, założyciel wrocławskiego Towarzystwa Wagnerowskiego.

10 T. Kruszewski, Rejestry podatkowe z XVI-XVIII w. jako źródto do badań historii nazw ulic we Wrocławiu, „Prawo CCXL. Studia Historycznoprawne”, Wrocław 1994, s. 155-167; Zmiany nazw ulic we Wrocławiu w latach Trzeciej Rzeszy, „Acta Universitatis Wratislavensis 1860. Studia nad Faszyzmem i Zbrodniami Hitlerowskimi” XIX, Wrocław 1996, s. 243-270.

11 K. Kędziora, Nazewnictwo ulic Wrocławia w latach 1945-1994, Warszawa 2012.

12 A. Jochelson, Jak powstawały polskie nazwy ulic i dzielnic w odzyskanym Wrocławiu, „Kalendarz Wrocławski”, Wrocław 1968, s. 228-232; Ulica Kazimierza Wielkiego, „Kalendarz Wrocławski”, Wrocław 1985, s. 303-311.

13 B. Siciński, Komisja Nazewnictwa Ulic, „Kalendarz Wrocławski”, Wrocław 1991, s. 86-87.

14 Z. Magdziarz, Zmiany nazw ulic widziane z drugiej strony, „Kalendarz Wrocławski”, Wrocław 1995, s. 90-91.

15 B. Jancewicz, Zmiany nazw wrocławskich ulic w 1989 roku, „Kalendarz Wrocławski”, Wrocław 1991, s. 86-87; idem, Zmiany nazw wrocławskich ulic w 1990 roku, „Kalendarz Wrocławski”, Wrocław 1992, s. 35-37; idem, Zmiany nazw wrocławskich ulic w 1991 roku, „Kalendarz Wrocławski”, Wrocław 1993, s. 61-63; idem, Zmiany nazw wrocławskich ulic w 1992 roku, „Kalendarz Wro-

Prawo 321, 2016

(C) for this edition by CNS 
Brakuje natomiast publikacji, które w sposób całościowy ujmowałyby prawne aspekty nazewnictwa ulic, tj. poruszały kwestie legitymacji do nadawania i zmian nazw ulic oraz kwestie proceduralne, badały treść aktów prawnych zmieniających nazwy ulic pod kątem zasad techniki prawodawczej. Jedynie T. Kruszewski poruszył tę problematykę w pozycji Prawne aspekty nazewnictwa ulic ${ }^{16}$. Również pisząca te słowa zajęła się tą tematyką, zwracając uwagę na istotną rolę ówczesnego aparatu administracyjnego, który stanął przed poważnym wyzwaniem przywrócenia szeroko pojętego ładu w powojennym Wrocławiu ${ }^{17}$. Niniejszy artykuł ma za zadanie wzbogacić dotychczasowy dorobek administracyjno-prawny w przedmiotowej tematyce.

Dla prawniczego dyskursu nieodzowne jest wskazanie obowiązujących $\mathrm{w}$ analizowanym okresie podstaw prawnych. Zmian nazewnictwa w mniejszym lub większym stopniu dotyczą następujące akty prawne:

1) Ustawa z dnia 10 grudnia 1920 r. o budowie i utrzymaniu dróg publicznych w Rzeczypospolitej Polskiej ${ }^{18}$,

2) Rozporządzenie Prezydenta Rzeczpospolitej z dnia 24 października 1934 r. o ustalaniu nazw miejscowości i numeracji nieruchomości ${ }^{19}$,

3) Ustawa z dnia 23 marca 1933 r. o częściowej zmianie ustroju samorządu terytorialnego ${ }^{20}$.

4) Uchwała Krajowej Rady Narodowej z dnia 1 stycznia 1944 r. — Statut tymczasowy rad narodowych ${ }^{21}$,

5) Ustawa z dnia 11 września 1944 r. o organizacji i zakresie działania rad narodowych ${ }^{22}$,

6) Dekret Polskiego Komitetu Wyzwolenia Narodowego z dnia 21 sierpnia 1944 r. o trybie powołania władz administracji ogólnej I-ej i II-ej instancji ${ }^{23}$,

cławski”, Wrocław 1994, s. 66-68; idem, Zmiany nazw wrocławskich ulic w 1993 roku, „Kalendarz Wrocławski”, Wrocław 1995, s. 88-90; idem, Nowe nazwy ulic we Wrocławiu w 1994 roku, „Kalendarz Wrocławski”, Wrocław 1996, s. 107-112; idem, Nowe nazwy ulic we Wrocławiu w 1995 roku, „Kalendarz Wrocławski”, Wrocław 1997, s. 192-198; idem, Nowe nazwy ulic we Wrocławiu w 1996 roku, „Kalendarz Wrocławski”, Wrocław 1998, s. 175-178; idem, Nowe nazwy ulic we Wrocławiu w 1997 roku, „Kalendarz Wrocławski”, Wrocław 1999, s. 170-173.

16 T. Kruszewski, Prawne aspekty nazewnictwa ulic, [w:] Nazwy Ulic Wrocławia, red. B. Jancewicz, L. Smołka, Wrocław 2000, s. 31-34.

17 M. Jankowska, Administracyjno-prawna problematyka zmiany nazewnictwa ulic Wroctawia w latach 1945-1946, „Folia Iuridica Wratislaviensis” 2, 2013, nr 1. W artykule tym skupiłam się głównie na problemach legitymacji do przeprowadzania zmian w nazewnictwie bezpośrednio po wyzwoleniu Wrocławia.

18 Dz.U. z 1921 r. Nr 6, poz. 32.

19 Dz.U. z 1934 r. Nr 94, poz. 850, Dz.U. z 1948 r. Nr 36, poz. 251.

20 Dz.U. z 1933 r. Nr 35, poz. 294.

21 Protokół I pos. plen. Krajowej Rady Narodowej s. 30-36, [w:] A. Gwiżdż, J. Zakrzewska, Konstytucja i podstawowe akty ustawodawcze Polskiej Rzeczypospolitej Ludowej, Warszawa 1958, s. $53-59$.

22 Dz.U. z 1946 r. Nr 3, poz. 26 z późn. zm.

23 Dz.U. z 1944 r. Nr 2, poz. 8, charakter pomocniczy. 
7) Dekret Polskiego Komitetu Wyzwolenia Narodowego z dnia 23 listopada 1944 r. o organizacji i zakresie działania samorządu terytorialnego ${ }^{24}$,

8) Ustawa $z$ dnia 20 marca 1950 r. o terenowych organach jednolitej władzy państwowej ${ }^{25}$, która znosi Ustawę z dnia 11 września 1944 r. o organizacji i zakresie działania rad narodowych,

9) Ustawa z dnia 25 stycznia 1958 r. o radach narodowych ${ }^{26}$,

10) Zarządzenie Ministra Gospodarki Komunalnej z dnia 28 czerwca 1968 r. o ustaleniu wytycznych w sprawie nadawania nazw ulicom i placom oraz numeracji nieruchomości ${ }^{27}$ stanowiące załącznik do Rozporządzenia Ministra Gospodarki Komunalnej z dnia 25 czerwca 1968 r. w sprawie numeracji nieruchomości ${ }^{28}$.

Celem niniejszych rozważań jest analiza nazewnictwa w rezultacie zmian granic administracyjnych powojennego Wrocławia, w następstwie których sukcesywnie przyłączano do miasta nowe osiedla. Za podstawy prawne badanego stanu faktycznego przyjmuję następujące akty prawne:

1) Ustawę z dnia 20 marca 1950 r. o terenowych organach jednolitej władzy państwowej,

2) Ustawę z dnia 25 stycznia 1958 r. o radach narodowych,

3) Zarządzenie Ministra Gospodarki Komunalnej z dnia 28 czerwca 1968 r. o ustaleniu wytycznych w sprawie nadawania nazw ulicom i placom oraz numeracji nieruchomości stanowiące załącznik do Rozporządzenia Ministra Gospodarki Komunalnej z dnia 25 czerwca 1968 r. w sprawie numeracji nieruchomości.

4) Pismo Przewodniczącego Wydziału Powiatowego Województwa Wrocławskiego do Zarządu Miejskiego w Złotoryi z dnia 17 lipca 1947 roku w związku z Zarządzeniem Kancelarii Cywilnej Prezydenta Rzeczpospolitej Polskiej L. dz. 89/Org/47 z dnia 17 marca 1947 r. ${ }^{29}$

Podstawy te określam mianem ,teoretycznych” ze względu na istniejąca w badanym przedziale czasowym faktyczną niezgodność pomiędzy organami mającymi ustawową legitymację do przeprowadzania zmian nazewnictwa ulic a organami, które zmiany te przeprowadziły.

24 Dz.U. z 1944 r. Nr 14, poz. 74, charakter pomocniczy.

25 Dz.U. z 1950, Nr 14, poz. 130.

26 Dz.U. z 1958 r. Nr 29, poz. 172, następnie Dz.U. z 1973 r. Nr 47, poz. 277 (tekst jednolity).

27 M.P. z 1968 r. Nr 30, poz. 197.

28 Dz.U. z 1968 r. Nr 23, poz. 151.

29 APWr O. w Legnicy, Zarząd Miejski w Złotoryi 45/50, sygn. 1, k. 24. Na treść pisma składają się wytyczne, jakich należy przestrzegać przy ustanawianiu i zmianie nazw ulic, m.in. zakazuje się używania na oznaczenie ulic nazwisk osób żyjących. Jest to bez wątpienia akt normatywny, jednak nie funkcjonuje on w zbiorach aktów normatywnych, jakimi są np. biuletyny czy monitory, jest dostępny jedynie jako materiał archiwalny. 


\section{Periodyzacja}

Powojenny Wrocław trzykrotnie zmieniał granice administracyjne. Każda $\mathrm{z}$ tych zmian wyznaczać będzie cezurę badawczą w przedmiotowym artykule. Zmian dokonała Rada Ministrów w drodze następujących rozporządzeń:

1) Rozporządzenie Rady Ministrów z dnia 14 grudnia 1950 r. w sprawie zmiany granic miast Wałbrzycha i Wrocławia włączające do granic miasta Wrocławia obręby katastralne ${ }^{30}$ :

a) Zakrzów, Zgorzelisko — z powiatu oleśnickiego,

b) Brochów, Klecina, Muchobór Wielki, Oporów, Ołtaszyn, Sołtysowice, Wojnów, Wojszyce — z powiatu wrocławskiego;

2) Rozporządzenie Rady Ministrów z dnia 31 marca 1970 r. w sprawie zmiany granic miasta Wrocławia i powiatu trzebnickiego w województwie wrocławskim $^{31}$ włączające wieś Pawłowice do granic miasta Wrocławia z gromady Łozina w powiecie trzebnickim;

3) Rozporządzenie Rady Ministrów z dnia 30 listopada 1972 r. w sprawie zmiany granic miast Krakowa, Poznania i Wrocławia ${ }^{32}$ włączające do granic miasta Wrocławia wsie:

a) Jarnołtów, Jerzmanowo, Osiniec, Strachowice, Kłokoczyce, Lipa Piotrowska, Polanowice, Rędzin, Świniary, Widawa — z powiatu wrocławskiego,

b) Marszowice, Mokra i Żar — z powiatu średzkiego.

\section{Uwarunkowania historyczne i analiza stanu prawnego}

Analizując problematykę przemianowywania ulic w okresie powojennej działalności polonizacyjnej, napotkałam poważny problem administracyjnoprawny. Problemem tym jest określenie trybu, w jakim należało dokonywać zmian w nazewnictwie oraz wskazanie organu, który miał ustawową legitymację do przeprowadzenia tych zmian. Sugerując się charakterem tytułów aktów prawnych enumeratywnie wyliczonych w punkcie 1., można stwierdzić, że są to akty zawierające w swej treści rozwiązanie problemu. Okazało się jednak, że aparat administracyjny zmuszony był w większym stopniu kierować się praktyczną koniecznościa, aniżeli przepisami prawa. Istniejące przepisy prawa przy próbie ich praktycznego zastosowania okazywały się niekompletne i niewystarczające.

30 Dz.U. z 1950 r. Nr 57, poz. 509.

31 Dz.U. z 1970 r. Nr 8, poz. 70.

32 Dz.U. z 1972 r. Nr 50, poz. 323. 
Zgodnie z Uchwałą Krajowej Rady Narodowej z dnia 1 stycznia 1944 r. Statut tymczasowy rad narodowych oraz z Ustawą z dnia 11 września 1944 r. o organizacji i zakresie działania rad narodowych organem właściwym do tego celu była miejska rada narodowa ${ }^{33}$. Statut był pierwszym, podjętym jeszcze w czasie wojny, aktem prawnym ustalającym organizację i zadania rad narodowych. Nadał on radom charakter tymczasowych podziemnych organów władzy narodu oraz tymczasowej politycznej reprezentacji narodu. Uznał je także za organizatorów i kierowników walki o wyzwolenie Polski spod okupacji niemieckiej. Z uwagi na nieistniejący jeszcze w tym czasie aparat wykonawczy, ten dualizm funkcji rad był wyjątkowy ${ }^{34}$. Ustawa o organizacji i zakresie działania rad narodowych nazywa rady narodowe (tworzone aż do $1954 \mathrm{r}$. nie w drodze wyborów, lecz w drodze delegowania) tymczasowymi organami ustawodawczymi i samorządowymi oraz nadaje im kompetencje w zakresie:

a) planowania działalności publicznej,

b) kontroli działalności organów wykonawczych (państwowych i samorządowych),

c) powoływania samorządowych organów wykonawczych ${ }^{35}$.

Art. $1 \S 1$ ustawy o organizacji i zakresie działania rad narodowych jest przepisem przejściowym, który do nowelizacji 3 stycznia 1946 r. brzmiał: „Do czasu powołania stałej politycznej reprezentacji Narodu, w myśl zasad Konstytucji z dnia 17 marca 1921 r. jako tymczasowe organy ustawodawcze i samorządowe na oswobodzonych od okupanta terenach Rzeczypospolitej Polskiej działają rady narodowe" ${ }^{36}$. Art. 2 Statutu tymczasowego rad narodowych wskazuje na systemowe funkcjonowanie rad: „Krajowa Rada Narodowa sprawuje władzę na obszarze całej Polski w oparciu o system terenowych rad narodowych. Rady narodowe opieraja swoją organizację na podziale administracyjnym państwa polskiego:

33 Ustawa o organizacji i zakresie działania rad narodowych została uchwalona przez Krajową Radę Narodową w dniu 11 września 1944 r. (Dz.U. z 1944 r. Nr 5, poz. 22). Ustawa była następnie trzykrotnie nowelizowana: ustawą z dnia 31 grudnia 1944 r. (Dz.U. z 1944 r. Nr 19, poz. 98), ustawą z dnia 6 maja 1945 r. (Dz.U. z 1945 r. Nr 17, poz. 93) i ustawą z dnia 3 stycznia 1946 r. (Dz.U. z 1946 r. Nr 3, poz. 19); następnie ustawa o organizacji i zakresie działania rad narodowych została zastąpiona w dniu 20 marca 1950 r. ustawą o terenowych organach jednolitej władzy państwowej; w mocy utrzymane zostały przepisy o tworzeniu, składzie i zmianach składu rad narodowych. Przepisy te uległy uchyleniu na podstawie ordynacji wyborczej do rad narodowych uchwalonej przez Sejm w dniu 25 września 1954 r.

34 Prawo administracyjne, red. J. Boć, Wrocław 2010, s. 189.

35 Ibidem, s. 189-190.

36 Po zmianie ustawą z dnia 3 stycznia 1946 r. art. 1 otrzymał następujące brzmienie: „§ 1. Do czasu powołania stałej politycznej reprezentacji Narodu, w myśl zasad Konstytucji z dnia 17 marca 1921 r., organem Narodu w zakresie ustawodawstwa oraz kontroli nad działalnością Rządu i w zakresie nadzoru nad radami narodowymi jest Krajowa Rada Narodowa”. Nowelą z 3 stycznia 1946 r. wprowadzono dodatkowo $\S 2$. w brzmieniu: „§ 2. Jako organy planowania działalności publicznej oraz kontroli nad rządowymi i samorządowymi organami wykonawczymi działają gminne, miejskie, powiatowe i wojewódzkie rady narodowe". 
1) Gminne rady narodowe obejmują obszar gmin.

2) Miejskie rady narodowe w miastach wydzielonych działają na prawach powiatowych rad narodowych, w pozostałych miastach na prawach gminnych rad narodowych".

Zgodnie z art. 2 ustawy o organizacji i zakresie działania rad narodowych rady funkcjonować miały w strukturze hierarchicznej:

a) Krajowa Rada Narodowa,

b) wojewódzkie rady narodowe,

c) powiatowe rady narodowe,

d) miejskie rady narodowe,

e) gminne rady narodowe.

Wydawać by się mogło, iż działanie rad narodowych ujęte zostało przez prawodawcę w sposób kompleksowy. Jednakże jest to jedynie złudzenie. Zarówno Statut tymczasowy rad narodowych, jak i ustawa o organizacji i zakresie działania rad narodowych, nie przewidują sytuacji przejściowych. Oba te akty prawne nie zawierają przejrzystych instrukcji, jak postępować w sytuacji, kiedy zwołanie rady narodowej jest ze względów obiektywnych niemożliwe. W Statucie tymczasowym rad narodowych $\mathrm{w}$ rozdziale o bezpieczeństwie pracy rad narodowych $\mathrm{w}$ art. 6 stwierdzono, że praca rad narodowych w warunkach okupacji musi podlegać surowym prawidłom konspiracji. W dalszej części tego samego artykułu prawodawca zauważył, że mogą wystąpić trudności związane z obradowaniem rad narodowych, i wówczas postanawia o przesunięciu głównego ciężaru pracy na prezydium rady narodowej. Nie dopuszcza w ogóle sytuacji całkowitego paraliżu uniemożliwiającego zwołanie rad narodowych, $\mathrm{z}$ jakim mieliśmy do czynienia w powojennym Wrocławiu. Ustawa o organizacji i zakresie działania rad narodowych w rozdziale poświęconym funkcjonowaniu rad narodowych w art. $18 \S 1$ określa, że posiedzenia rad narodowych wojewódzkich, powiatowych, miejskich i gminnych odbywają się obligatoryjnie przynajmniej raz na miesiąc, a KRN — przynajmniej raz na kwartał. Ustawa nie przewiduje jednak następstw, jakie wyniknęły z braku możliwości sprostania tejże regulacji. Poprawność legislacyjna i skuteczność obydwu tych aktów prawnych z punktu widzenia funkcji administracji w życiu społecznym oraz funkcji prawa administracyjnego w ogóle jest w mojej ocenie niedostateczna.

W latach 1945-1946 nie funkcjonuje we Wrocławiu organ, w którego kompetencji leży nadawanie nazw ulicom, ponieważ nie istniał polski elektorat umożliwiający jego wybór, a co za tym idzie - utworzenie stosownego organu. O tyle, o ile przepisy na szczeblu centralnym starały się sprostać sytuacjom epizodycznym, o tyle na szczeblu lokalnym brakuje przepisów regulujących postępowanie w sytuacjach skrajnie kryzysowych, jaką był powojenny nieład. Taki stan rzeczy zrodził swoisty passus - funkcjonalną, ściśle praktyczną konieczność zmiany nazewnictwa ulic. Wyrazem tej konieczności było samoistne wyposażenie się pionierskiego Zarządu Miejskiego miasta Wrocławia w kompetencje administracyjnoprawne do przeprowadzania zmian nazewnictwa oraz wprowadzanie zmian za pomocą okólników. 
Potrzeba chwili przesądziła poniekąd o przyjęciu powyższej uproszczonej procedury zmiany nazewnictwa. W mojej ocenie bardziej racjonalne wydawałoby się zaczerpnięcie rozwiązania z polskiej legislacyjnej przeszłości, dokładnie z Dekretu z 22 listopada 1918 r. o najwyższej władzy reprezentacyjnej Republiki Polskiej ${ }^{37}$. Dekret ten przyjął w art. 3: „Projekty ustawodawcze, uchwalone przez Radę Ministrów, ulegają mojemu zatwierdzeniu ${ }^{38}$ i uzyskują moc obowiązująca, o ile sama ustawa inaczej nie stanowi, z chwilą ogłoszenia w Dzienniku Praw Państwa Polskiego; tracą one moc obowiązująca, o ile nie będą przedstawione na pierwszym posiedzeniu Sejmu Ustawodawczego do jego zatwierdzenia”. Oznacza to, iż dopóki nie ma faktycznej możliwości zwołania sejmu ustawodawczego, władza ustawodawcza powierzona zostaje władzy wykonawczej. Wszelkie projekty ustawodawcze rządu muszą jednak zostać przedłożone sejmowi ustawodawczemu ${ }^{39}$ na najbliższym posiedzeniu w celu zatwierdzenia pod rygorem utraty mocy obowiązującej.

Kolejny legislacyjny problem pojawia się w okresie, w którym po raz pierwszy w powojennym Wrocławiu została zwołana miejska rada narodowa. Okazuje się, iż mamy do czynienia z nadmiarem ustawodawstwa. Oprócz ustawy o organizacji i zakresie działania rad narodowych obowiązuje przecież Ustawa z dnia 23 marca 1933 r. o częściowej zmianie ustroju samorządu terytorialnego, zwana ustawą scaleniową. Należy zwrócić uwagę, że ustawa ta nie została uchylona. W myśl zasad techniki prawodawczej nie można także uznać, że zastapił ją inny akt prawny, jeśli nie wyraża on tego wprost. Konieczne jest rozstrzygnięcie na gruncie doktryny prawa, która ustawa jest obowiązująca. Kwestia ta zostaje jednoznacznie uporządkowana dopiero w roku 1950 po wejściu w życie Ustawy z dnia 20 marca 1950 r. o terenowych organach jednolitej władzy państwowej, która zniosła Ustawę z dnia 11 września 1944 r. o organizacji i zakresie działania rad narodowych.

\section{Dokumentacja prawna}

Na podstawie wymienionych w punkcie 2. rozporządzeń przyłączono do Wrocławia nowe tereny. Trzy zmiany granic miasta przyjęłam jako podokresy, w ramach których sukcesywnie dokonuje się przemianowania nazw ulic powtarzających

37 Dz. P.P.P. z 1918 r. Nr 17, poz. 41; wydany na podstawie Dekretu Naczelnego Dowódcy Józefa Piłsudskiego z 14 listopada 1918 r. (Dz.P.P.P. z 1918 r. Nr 17, poz. 40).

38 Zatwierdzeniu Tymczasowego Naczelnika Państwa Józefa Piłsudskiego.

39 Zgodnie z Dekretem Naczelnego Dowódcy Józefa Piłsudskiego z 14 listopada 1918 r. (Dz.P.P.P. z 1918 r. Nr 17, poz. 40) jedynym organem mającym legitymację do tworzenia aktów prawnych jest sejm ustawodawczy: „Z natury położenia Polski jest charakter rządu aż do czasu zwołania Sejmu Ustawodawczego prowizorycznym i nie dozwala na przeprowadzenie głębokich zmian społecznych, które uchwalić może tylko Sejm Ustawodawczy. Przekonany, że twórcą praw narodu może być tylko Sejm, żądałem zwołania go w możliwie krótkim, kilkumiesięcznym terminie". 
się. Każda administracyjna zmiana granic miasta powodowała, że radni miejscy dostrzegali konieczność usuwania zdublowanych nazw, nadając nowe brzmienie zazwyczaj ulicom na włączonej wsi ${ }^{40}$. W oparciu o analizę uchwał, map Wrocławia oraz rozmowy z prof. dr. hab. T. Kruszewskim postanowiłam podjąć próbę wyliczenia nazw ulic przemianowanych z przyczyn powtarzającego się nazewnictwa.

\subsection{Zmiany nazewnictwa ulic w rezultacie rozwoju terytorialnego Wrocławia w 1950 roku}

Po wejściu w życie Rozporządzenia Rady Ministrów z dnia 14 grudnia 1950 r. w sprawie zmiany granic miast Wałbrzycha i Wrocławia włączono do granic miasta Wrocławia wsie Zakrzów, Zgorzelisko, Brochów, Klecinę, Muchobór Wielki, Oporów, Ołtaszyn, Sołtysowice, Wojnów i Wojszyce. Problem podwójnych, czasem nawet potrójnych i poczwórnych tożsamych nazw był niemały, określenia nazw ulic i placów przyłączonych wsi notorycznie pokrywały się z nazwami już we Wrocławiu funkcjonującymi. Radni aż pięciokrotnie próbowali zaprowadzić porządek w mieście, uchwalając następujące akty prawne:

1) Uchwała nr 102 Miejskiej Rady Narodowej z dnia 22 listopada 1952 r.,

2) Uchwała nr 115 Miejskiej Rady Narodowej z dnia 22 grudnia 1952 r.,

3) Uchwała nr 4/56 Miejskiej Rady Narodowej z dnia 23 stycznia 1956 r.,

4) Uchwała nr 26/56 Miejskiej Rady Narodowej z dnia 23 listopada 1956 r.,

5) Uchwała nr 33/59 Rady Narodowej Miasta Wrocławia z dnia 30 grudnia $1959 \mathrm{r}^{41}$

W Uchwale nr 102 Miejskiej Rady Narodowej z dnia 22 listopada 1952 r. radni dostrzegli problem istnienia $\mathrm{w}$ mieście aż ośmiu ulic Polnych ${ }^{42}$.

Tabela 1. przedstawia zmiany, jakie wprowadzono w I punkcie uchwały.

Tabela 1. Nazwy ulic zmienione Uchwałą nr 102 Miejskiej Rady Narodowej z dnia 22 listopada 1952 r. z powodu konieczności usunięcia powtarzającego się nazewnictwa

\begin{tabular}{|c|l|l|l|}
\hline L.p. & Nazwa przed zmianą & Położenie ulicy & \multicolumn{1}{|c|}{ Nazwa po zmianie } \\
\hline 1 & Polna & miasto Wrocław & Stefana Jaracza \\
\hline 2 & Polna & Klecina & Łanowa \\
\hline
\end{tabular}

40 Niejednokrotnie kierując się względami praktycznymi czy też opinią społeczną, zmieniano nazwę w mieście, zachowując tym samym dotychczasową nazwę ulicy na wsi. Takie sytuacje sygnalizuję w tabelach, określając położenie ulicy jako „miasto Wrocław”.

41 Wymienionymi w punkcie 1-5 uchwałami Miejskiej Rady Narodowej dysponuję dzięki uprzejmości prof. dr. hab. T. Kruszewskiego (zbiory prywatne). Oryginały znajdują się w AP we Wrocławiu.

42 Uchwała nr 102 Miejskiej Rady Narodowej z dnia 22 listopada 1952 r. 


\begin{tabular}{|c|l|l|l|}
\hline 3 & Polna & Ołtaszyn $^{43}$ & Łubinowa \\
\hline 4 & Polna & Oporów & Leszczynowa \\
\hline 5 & Polna & Wojnów & Ubocze \\
\hline 6 & Polna & Zgorzelisko & Dłutowa \\
\hline 7 & Polna & Wojszyce & Burzańska \\
\hline 8 & Polna & Muchobór & $\begin{array}{l}\text { włączono do Głównej jako jej } \\
\text { przedłużenie }\end{array}$ \\
\hline
\end{tabular}

Źródło: opracowanie własne na podstawie analizy treści Uchwały nr 102 Miejskiej Rady Narodowej $\mathrm{z}$ dnia 22 listopada $1952 \mathrm{r}$.

W treści uchwały zaznaczono, że Miejska Rada Narodowa dokonuje powyższych zmian jednogłośnie, na wniosek Komisji Nazewnictwa Ulic. Komisję, o której mowa w powyższej uchwale, powołano 21 grudnia 1950 r. ${ }^{44}$ Była to Niestała Komisja Nazewnictwa Ulic powołana „dla opracowania wniosków o zmianę nazw ulic i placów we Wrocławiu” 45 . Powstała z potrzeby uporządkowania „nazw niestosownych, niejednokrotnie wprowadzających w błąd, a także niejednokrotnie nasuwających zastrzeżenie ze względów historycznych i politycznych"46. Rzeczą wartą zastanowienia jest okoliczność uznania Komisji Nazewnictwa Ulic za wnioskodawcę zmian. Na gruncie prawa administracyjnego rozstrzygnąć należałoby nasuwającą się wątpliwość, czy wniosek Komisji Nazewnictwa Ulic może zostać uznany za podstawę prawną zmian. Można wysnuć przypuszczenie, że sformułowanie „na wniosek Komisji Nazewnictwa Ulic” zostało umieszczone celowo w zdaniu wprowadzającym uchwały. Uchwała ta oprócz porządkowania powielającego się nazewnictwa wprowadza także nieśmiało pierwsze ideologicznie nacechowane nazwy ulic. Przemianowuje bowiem ulicę Wałbrzyską na ulicę Przyjaźni Polsko-Radzieckiej, nie podając ku temu wyraźnej przyczyny.

43 W uchwale funkcjonuje nazwa Ołtarzyn (niem. Oltaschin, od 1937 do 1945 Herzogshufen, w pierwszych latach po II wojnie światowej Ołtarzyn). W mojej ocenie powojenna nazwa funkcjonowała w takiej postaci z uwagi na jak najdalsze odchodzenie od nazewnictwa niemieckiego, stąd spolszczenie mające kojarzyć się z „ołtarzem”. W późniejszych latach powrócono do współczesnej nazwy Ołtaszyn, która jest bliższa zlatynizowanej formie Oltauschino. Nazwa ta pojawiła się w najstarszym znanym zapisie dotyczącym wsi z 1204 r., w którym Henryk Brodaty m.in. zwolnił posiadłości klasztoru NMP na Piasku od daniny na prawie polskim iure polonico zwanej podworowem, o czym mowa w C. Grünhagen, Regesten zur Schlesischen Geschichte, Breslau, 1884-1886.

44 APWr, Prezydium Rady Narodowej miasta Wrocławia, 1, Protokół VI sesji Miejskiej Rady Narodowej we Wrocławiu, 21 grudnia 1950 r., k. 205.

45 Należy zaznaczyć, że była to komisja radnych. Obecna Komisja Nazewnictwa Ulic działająca przy Towarzystwie Miłośników Wrocławia powstała jako ciało społeczne w 1956 r. i nie jest sukcesorem komisji powołanej w $1950 \mathrm{r}$.

46 APWr, Prezydium Rady Narodowej miasta Wrocławia, 1, Protokół VI sesji Miejskiej Rady Narodowej we Wrocławiu, 21 grudnia 1950 r., k. 205. 
W Uchwale nr 115 Miejskiej Rady Narodowej we Wrocławiu z dnia 22 grudnia 1952 r. zmieniono kolejne powtarzające się nazwy. Niektóre z nich powtarzały się nawet kilkukrotnie.

Tabela 2. Nazwy ulic zmienione Uchwałą nr 115 Miejskiej Rady Narodowej z dnia 22 grudnia 1952 r. z powodu konieczności usunięcia powtarzającego się nazewnictwa

\begin{tabular}{|c|l|l|l|}
\hline L.p. & \multicolumn{1}{|c|}{ Nazwa przed zmianą } & \multicolumn{1}{|c|}{ Położenie ulicy } & \multicolumn{1}{|c|}{ Nazwa po zmianie } \\
\hline 1 & Mickiewicza & Radwanice & Radwanicka $^{47}$ \\
\hline 2 & Curie-Skłodowskiej & Oporów & Teodora Duracza \\
\hline 3 & Dębowa & Jagodno & Jagodzińska \\
\hline 4 & Długa & Muchobór & Kunickiego \\
\hline 5 & Dworcowa & Klecina & Antoniego Galińskiego \\
\hline 6 & Dworska & Wojszyce & włączono do ul. Brochowskiej \\
\hline 7 & Dworska & Muchobór & Lisia \\
\hline 8 & Główna & Brochów & $\begin{array}{l}\text { włączono do ul. Wolności } \\
\text { zmieniono obie na } \\
\text { ul. Małgorzaty Fornalskiej }\end{array}$ \\
\hline 9 & Główna & Strachowice & Iwana Pawłowa \\
\hline 10 & Główna & Wojnów & włączono do ul. Strachocińskiej \\
\hline 11 & Graniczna & Brochów & Popielskiego \\
\hline 12 & Granicza & Ołtaszyn & $\begin{array}{l}\text { włączono do ul. Strażackiej } \\
\text { i zmieniono obie na ul. Nenckiego }\end{array}$ \\
\hline 13 & Wincentego Kadłubka & miasto Wrocław & Maksyma Gorkiego ${ }^{49}$ \\
\hline 14 & Katarzyńska & Bieńkowice & Pięćdziesięciu Bohaterów \\
\hline 15 & Katarzyńska & Ołtaszyn & Kurpiów ${ }^{50}$ \\
\hline 16 & Marii Konopnickiej & Zgorzelisko & Sienna \\
\hline 17 & Marii Konopnickiej & Radwanice & Bracka ${ }^{51}$ \\
\hline 18 & Marii Konopnickiej & Zakrzów & Stoczniowska \\
\hline
\end{tabular}

47 To przemianowanie jest o tyle ciekawe, że Radwanice nigdy nie zostały włączone do Wrocławia. Świadczy to prawdopodobnie o niewiedzy ówczesnych radnych lub o planowanym wcieleniu Radwanic do Wrocławia.

48 Zmiana w efekcie przyniosła zdublowanie nazwy ulicy w mieście.

49 Zmieniono nazwę ulicy w mieście, żeby zachować nazwę ulicy na przyłączonej wsi.

50 Zmiana aż dwóch nazw ulic Katarzyńskich nie była konieczna, ponieważ w mieście Wrocław nie było ulicy o takiej nazwie.

51 Powiela się zmiana nazwy w Radwanicach, których nigdy nie wcielono do Wrocławia. 


\begin{tabular}{|c|c|c|c|}
\hline 19 & Polna & Maślice & Gminna $^{52}$ \\
\hline 20 & Mickiewicza & Klecina & $\begin{array}{l}\text { włączono do ul. Klecińskiej jako } \\
\text { jej przedłużenie } 53\end{array}$ \\
\hline 21 & Mickiewicza & Zakrzów & Konrada Wallenroda \\
\hline 22 & Mickiewicza & Brochów & Leonarda da Vinci \\
\hline 23 & Mickiewicza & Oporów & Hertza Benedykta ${ }^{54}$ \\
\hline 24 & Mickiewicza & Ołtaszyn & Miczurina \\
\hline 25 & Mickiewicza & Muchobór & Belojanisa \\
\hline 26 & Mickiewicza & Gorlice & Rzeczna \\
\hline 27 & Ogrodowa & Ołtaszyn & Traktorowa \\
\hline 28 & Ogrodowa & Wojszyce & Kombajny \\
\hline 29 & Ogrodowa & Brochów & Zwrotnicza \\
\hline 30 & Ogrodowa & Klecina & Cukrowa \\
\hline 31 & Ogrodowa & Zakrzów & Łuczników \\
\hline 32 & Ogrodowa & Muchobór & Zagony \\
\hline 33 & Ogrodowa & Wojnów & Strumykowa \\
\hline 34 & Ogrodowa & Zgorzelisko & Fuczika Juliusza \\
\hline 35 & Ogrodowa & Oporów & Balzaka \\
\hline 36 & Kolejowa & Brochów & Semaforowa \\
\hline 37 & Kolejowa & Muchobór & Avicenny \\
\hline 38 & Kolejowa & Wojszyce & Czechowa \\
\hline 39 & Kolejowa & Maślice & Narzędziowa \\
\hline 40 & Wrocławska & Oporów & Wiktora Hugo $^{55}$ \\
\hline 41 & $\begin{array}{l}\text { Wrocławska i Przyjaciół } \\
\text { Żołnierza }\end{array}$ & Brochów & 22 Lipca \\
\hline 42 & Wrocławska & Muchobór & $\begin{array}{l}\text { połączono z ul. z Małkowicką } \\
\text { i nazwano ul. Ostrowskiego }\end{array}$ \\
\hline 43 & Wrocławska & Sołtysowice & włączono do ul. Sołtysowickiej \\
\hline 44 & Wrocławska & Wojszyce & połączono z ul. Wiśniową \\
\hline
\end{tabular}

52 Pomimo przemianowania 8 ulic Polnych Uchwałą nr 102 Miejskiej Rady Narodowej z dnia 22 listopada 1952 r., miesiąc później dostrzeżono potrzebę przemianowania jeszcze jednej ul. Polnej.

53 W uchwale błędnie wskazano „ul. Mickiewicza w Oporowie” zamiast w Klecinie.

54 W uchwale błędnie wskazano „ul. Mickiewicza w Klecinie” zamiast w Oporowie.

${ }^{55} \mathrm{~W}$ mieście Wrocław nie może funkcjonować ul. Wrocławska, byłaby to nazwa ośmieszająca. 


\begin{tabular}{|c|l|l|l|}
\hline 45 & Wrocławska & Zakrzów & Makarenki \\
\hline 46 & Wrocławska & Zgorzelisko & Szewczenki \\
\hline
\end{tabular}

Źródło: opracowanie własne na podstawie analizy treści Uchwały nr 115 Miejskiej Rady Narodowej z dnia 22 grudnia $1952 \mathrm{r}$.

Powyższa uchwała zmienia w sumie 58 nazw ulic, z czego 46 z powodu ich powtarzania się. W tej uchwale także przejawia się tendencja nadawania nazw ideologicznych. Powielone nazewnictwo i konieczność jego uporządkowania staje się okazją dla ówczesnych władz do przeforsowania ideologicznych zmian.

Znamienne jest na przykład przemianowanie Placu Konstytucji 3-go Maja na Plac Konstytucji czy też ulicy Adama Mickiewicza w Muchoborze na ulicę Belojanisa $^{56}$. Analizie tej uchwały towarzyszy wrażenie niedbalstwa i braku konsekwencji w podawaniu imion patronów ulicy. Przypadkowość decyduje o tym, czy podaje się imię patrona, czy też nie. Przykładowo imię patrona pojawia się przy zmianie ul. Wincentego Kadłubka na ul. Maksyma Gorkego, ale już zmiany ulic Adama Mickiewicza na ul. Miczurina czy ul. Belojanisa lub ul. Ogrodowej na ul. Balzaka dokonuje się bez wskazania imienia patrona. Tendencja ta zauważalna będzie również w kolejnych analizowanych uchwałach, jednak z czasem radni będą dokonywać zmian z większą dokładnością i precyzją. Każda nazwa podana w niniejszym artykule brzmi dokładnie tak, jak w analizowanych uchwałach i celowo nie została skorygowana.

Choć zadaniem Niestałej Komisji Nazewnictwa Ulic było uporządkowanie nazw ulic we Wrocławiu i nowo przyjętych osiedlach w taki sposób, żeby „nie zaszła potrzeba za rok ponownie do tego wracać" ${ }^{57}$, to już w $1956 \mathrm{r}$. idea ta upadła. Radni zorientowali się, że nadal istnieje dezorganizacja wynikająca z powtarzającego się nazewnictwa, w związku z czym 23 stycznia 1956 r. została podjęta Uchwała nr 4/56 Miejskiej Rady Narodowej.

Tabela 3. Nazwy ulic zmienione Uchwałą nr 4/56 Miejskiej Rady Narodowej z dnia 23 stycznia 1956 r. z powodu konieczności usunięcia powtarzającego się nazewnictwa

\begin{tabular}{|c|l|l|l|}
\hline L.p. & \multicolumn{1}{|c|}{ Nazwa przed zmianą } & \multicolumn{1}{|c|}{ Położenie ulicy } & \multicolumn{1}{|c|}{ Nazwa po zmianie } \\
\hline 1 & Brochowska & Wojszyce & Terenowa \\
\hline 2 & Bardzka & Jagodno & Buforowa \\
\hline 3 & Białoruska & Muchobór & Mińska \\
\hline 4 & Dworcowa & Wojszyce & Przystankowa \\
\hline 5 & Dąbrowskiego & Ołtaszyn & Kryniczna \\
\hline
\end{tabular}

56 Nikos Belojanis — grecki działacz ruchu komunistycznego, antyhitlerowskiego ruchu oporu.

57 Archiwum Państwowe we Wrocławiu, Prezydium Rady Narodowej miasta Wrocławia, 331, Protokół nr 1 posiedzenia Niestałej Komisji Nazewnictwa Ulic, 25 stycznia 1951 r., k. 1. 


\begin{tabular}{|c|c|c|c|}
\hline 6 & Główna (Małgorzaty Fornalskiej) & Brochów & Centralna, Wolności ${ }^{58}$ \\
\hline 7 & Grunwaldzka & Muchobór & Husycka \\
\hline 8 & Kadłubka & miasto Wrocław & Bociania \\
\hline 9 & Kołłątaja & Oporów & Ariańska \\
\hline 10 & Kościelna & Brochów & Biegła \\
\hline 11 & Kościuszki & Brochów & Henryka Rutkowskiego \\
\hline 12 & Kościuszki (Mickiewicza) & Ołtaszyn & Iwana Miczurina $^{59}$ \\
\hline 13 & Kościuszki & Muchobór & Karpacka \\
\hline 14 & Krótka & Wojszyce & Daleka \\
\hline 15 & Krótka & Sołtysowice & Bagatela \\
\hline 16 & Krótka & Wojnów & Odcinek \\
\hline 17 & Kopernika & Brochów & Władysława Hibnera \\
\hline 18 & Kopernika & Oporów & Karola Darwina \\
\hline 19 & Kopernika & Zakrzów & Wilczkowska \\
\hline 20 & Lipowa & Brochów & Woskowa \\
\hline 21 & Lipowa & Ołtaszyn & Pszczelarska \\
\hline 22 & Lipowa & Wojszyce & Pawia \\
\hline 23 & Lipowa & Jagodno & Otmuchowska \\
\hline 24 & Lwowska & Zgorzelisko & Kownieńska \\
\hline 25 & Lotnicza & Muchobór & Rakietowa \\
\hline 26 & Lelewela & Oporów & Brukselska \\
\hline 27 & Łąkowa & Oporów & Jordanowska \\
\hline 28 & Łąkowa & Sołtysowice & Torfowa \\
\hline 29 & Łódzka & Muchobór & Łaska \\
\hline 30 & Modrzewskiego & Oporów & Jana Ostroroga \\
\hline 31 & Piękna & Brochów & Władysława Kniewskiego \\
\hline 32 & Piękna & Wojszyce & Będzińska \\
\hline
\end{tabular}

58 W uchwale wskazuje się przemianowanie ul. Głównej na ul. Centralną, lecz zapomniano, że w Uchwale nr 115 Miejskiej Rady Narodowej we Wrocławiu z dnia 22 grudnia 1952 r. przemianowano już ul. Główną na ul. Małgorzaty Fornalskiej. Z analizy map wynika również, że przemianowano nie tylko ul. Centralną, ale także ul. Wolności.

59 Jeśli dać wiarę dokumentacji prawnej, to zdublowano w ten sposób ul. Miczurina, ponieważ wcześniej Uchwałą nr 115 Miejskiej Rady Narodowej we Wrocławiu z dnia 22 grudnia 1952 r. przemianowano ul. Mickiewicza na Ołtaszynie na ul. Miczurina. Pojawia się wątpliwość, czy jest to przeoczenie radnych, czy też niewykonanie poprzedniej zmiany w terenie (brak tabliczek). 


\begin{tabular}{|c|c|c|c|}
\hline 33 & Piękna & Oporów & Podgórska \\
\hline 34 & Polna (Burzańska) & Wojszyce & Morska $^{60}$ \\
\hline 35 & Prosta & Bieńkowice & Semaforowa ${ }^{61}$ \\
\hline 36 & Petrażyckiego & miasto Wrocław & Dr. Roberta Kocha ${ }^{62}$ \\
\hline 37 & Roosvelta & Zakrzów & Orna \\
\hline 38 & Rzeźnicza & Wojszyce & Snopkowa \\
\hline 39 & Różana & Zgorzelisko & Bławatna \\
\hline 40 & Sikorskiego & Ołtaszyn & Strączkowa \\
\hline 41 & Spokojna & miasto Wrocław & Aleksandra Zelwerowicza \\
\hline 42 & Sportowa & Bieńkowice & Boiskowa \\
\hline 43 & Sportowa & Muchobór & Trawowa \\
\hline 44 & Sienkiewicza & Zgorzelisko & Mroźna \\
\hline 45 & Sienkiewicza & Zakrzów & Księżycowa \\
\hline 46 & Słoneczna & Bieńkowice & Wieczna \\
\hline 47 & Słoneczna & miasto Wrocław & Iwana Pawłowa ${ }^{63}$ \\
\hline 48 & Słowackiego & Klecina & Balladyny \\
\hline 49 & Słowackiego & Zgorzelisko & Kordiana \\
\hline 50 & Stalina & Sołtysowice & Jerzego Leńskiego \\
\hline 51 & Stalina & Zakrzów & Warszawska \\
\hline 52 & Szkolna & Ołtaszyn & Uczniowska \\
\hline 53 & Szkolna & Sołtysowice & Lekcyjna \\
\hline 54 & Szkolna & Wojnów & Wykładowa \\
\hline 55 & Szkolna & Zakrzów & Pedagogiczna \\
\hline 56 & Traugutta & Brochowie & Społeczna \\
\hline 57 & Wąską & Wojszycach & Wylotna \\
\hline
\end{tabular}

${ }^{60}$ Ul. Polna w Wojszycach została uprzednio przemianowana Uchwałą nr 102 Miejskiej Rady Narodowej z dnia 22 listopada $1952 \mathrm{r}$.

${ }^{61}$ Ul. Semaforowa istnieje już we Wrocławiu w efekcie przemianowania ul. Kolejowej na Brochowie Uchwałą nr 115 Miejskiej Rady Narodowej we Wrocławiu z dnia 22 grudnia 1952 r.

62 Zwyczajowo w nazwach ulic nie podaje się stopni naukowych. Jednorazowe podanie stopnia naukowego w tym wypadku mogło świadczyć o niedbalstwie urzędników albo stanowiło zabieg celowy ku odparciu zarzutów, że czci się w ten sposób jakiegoś bliżej nieokreślonego Niemca, a może nawet zbrodniarza Ericha Kocha - w tych czasach mogło się to szczególnie źle kojarzyć.

${ }^{63}$ Ul. Iwana Pawłowa istnieje już we Wrocławiu w efekcie przemianowania ul. Głównej na Strachowicach Uchwałą nr 115 Miejskiej Rady Narodowej we Wrocławiu z dnia 22 grudnia 1952 r. 


\begin{tabular}{|c|l|l|l|}
\hline 58 & Włodkowica & Oporów & Maksyma Gorkego \\
\hline 59 & Wiejska & Zgorzelisko & Miejska \\
\hline 60 & Zielona & Brochów & Chmurna \\
\hline 61 & Rolnicza & Bieńkowice & Ziemniaczana \\
\hline
\end{tabular}

Źródło: opracowanie własne na podstawie analizy treści Uchwały nr 4/56 Miejskiej Rady Narodowej z dnia 23 stycznia $1956 \mathrm{r}$.

Uchwała zmienia 62 nazwy ulic, z czego 61 zostało przemianowanych z powodu ich powtarzalności. Można stwierdzić, że uchwała została w całości ustanowiona do tego celu. Nadal widoczne jest niedbalstwo i niekonsekwencja w używaniu imion czy też tytułów naukowych. Zasadniczo nie stosuje się tytułów naukowych w nazewnictwie ulic, jednak z niewiadomej przyczyny podano tytuł doktora przy zmianie ul. Petrażyckiego na ul. Dr. Roberta Kocha, choć niejednokrotnie pominięto wyższe tytuły naukowe innych patronów.

Kolejnym aktem prawnym z lat 50. XX wieku jest Uchwała nr 26/56 Miejskiej Rady Narodowej z dnia 23 listopada 1956 r. Jest to pierwsza z analizowanych przeze mnie w niniejszym artykule uchwal, w której podano podstawę prawną zmian. Mianowicie przemianowań nazewnictwa dokonano zgodnie z Ustawą o terenowych organach jednolitej władzy państwowej z dnia 20 marca 1950 r., ale także w oparciu o postulaty mieszkańców. Zmian dokonuje się w celu ,przywrócenia niektórym ulicom ich nazw historycznych, jak również uporządkowania powtarzających się nazw"64. Miejska Rada Narodowa ponownie dokonuje zmian na wniosek Komisji Nazewnictwa Ulic, nazwanej „Komisja do Zmian Nazw Ulic”. Należy jednak zaznaczyć, że nie jest to ta sama komisja radnych, która pojawiała się we wcześniejszych uchwałach jako wnioskodawca. Jest to już bowiem społeczna Komisja Nazewnictwa Ulic — ta sama, która działa obecnie przy Towarzystwie Miłośników Wrocławia.

Uchwała zmienia 52 nazwy ulic, z czego 32 zostały przemianowane z powodu powtarzalności. Uchwała ta zapoczątkowała proces zmiany nazw nacechowanych ideologią komunistyczną, o czym najpełniej świadczy vacatio legis wprowadzanych niniejszą uchwałą zmian. Otóż w odniesieniu do przemianowania ulicy Stalina ${ }^{65}$ uchwała weszła w życie z „mocą natychmiastową”, w odniesieniu zaś do pozostałych zmian — z dniem 21 stycznia $1957 \mathrm{r} .{ }^{66}$

64 Preambuła Uchwały nr 26/56 Miejskiej Rady Narodowej z dnia 23 listopada 1956 r.

${ }^{65} \mathrm{Z}$ ustnych przekazów Andrzeja Jochelsona wiadomo, że nazwa ul. Stalina została przemianowana jeszcze przed wejściem w życie niniejszej uchwały. Samowolnie, pod osłoną nocy odkręcono tabliczki z nazwą ul. Stalina i zmieniono początkowo na ul. Węgierską, co miało upamiętniać powstanie węgierskie (próbę narodu węgierskiego a uwolnienia się spod sowieckiej dominacji) i wyrażać solidarność z narodem węgierskim, a następnie na ul. Jedności Narodowej.

66 Uchwała nr 26/56 Miejskiej Rady Narodowej z dnia 23 listopada 1956 r. 
Tabela 4. Nazwy ulic zmienione Uchwałą nr 26/56 Miejskiej Rady Narodowej z dnia 23 listopada 1956 r. z powodu konieczności usunięcia powtarzającego się nazewnictwa Miejskiej Rady Narodowej z dnia 23 stycznia 1956 r.

\begin{tabular}{|c|l|l|l|}
\hline L.p. & \multicolumn{1}{|c|}{ Nazwa przed zmianą } & Położenie ulicy & \multicolumn{1}{|c|}{ Nazwa po zmianie } \\
\hline 1 & Kościuszki (Iwana Miczurina) & Ołtaszyn & Konstantego Gałczyńskiego $^{67}$ \\
\hline 2 & Lipowa & Jagodno & Jerzego Rynga \\
\hline 3 & Polna (Morska) & Wojszyce & Juliana Bruna $^{68}$ \\
\hline 4 & Prosta (Semaforowa) & Bieńkowice & Bronisława Wesołowskiego $^{69}$ \\
\hline 5 & Rejtana & Muchobór & Feliksa Kona \\
\hline 6 & Stalina (Warszawska) & Zakrzów & Adolfa Warskiego \\
\hline 7 & Włodkowica (Maksyma & Oporów & Henryka Heinego \\
\hline 8 & Dw1 & Reformy Rolnej \\
\hline 9 & Wiśniowa & Muchobór & Róży Luksemburg \\
\hline 10 & Boczna & Ołtaszyn & Radarowa \\
\hline 11 & Browarna & Wojszyce & Chmielna \\
\hline 12 & Główna & Zakrzów & Karola Liebknechta \\
\hline 13 & Kościelna & Muchobór & Parafialna \\
\hline 14 & Klecińska & Wojszyce & Kostrzyńska \\
\hline 15 & Mokra & Oporów & Poronińska \\
\hline 16 & Młyńska & Wojszyce & Ryżowa \\
\hline
\end{tabular}

67 Powtarza się sytuacja z pominięciem dokonanych uprzednio zmian. Zapomniano, że przemianowano już ul. Kościuszki w Ołtaszynie na ul. Iwana Miczurina Uchwałą nr 4/56 Miejskiej Rady Narodowej z dnia 23 stycznia 1956 r., a także wcześniej, bo Uchwałą nr 115 Miejskiej Rady Narodowej we Wrocławiu z dnia 22 grudnia 1952 r. przemianowano ul. Mickiewicza na Ołtaszynie na ul. Miczurina.

68 Ul. Polna w Wojszycach została uprzednio przemianowana na ul. Burzańską Uchwałą nr 102 Miejskiej Rady Narodowej z dnia 22 listopada 1952 r., pominięto jednak tę zmianę i ponownie przemianowano ul. Polną na ul. Morską Uchwałą nr 4/56 Miejskiej Rady Narodowej z dnia 23 stycznia 1956 r. Najwyraźniej w stosunku do ul. Polnej na Wojszycach uchwały te nie zostały wykonane, ponieważ po raz trzeci dokonuje się przemianowania ul. Polnej, tym razem na ul. Juliana Bruna.

${ }^{69}$ U1. Prosta w Bieńkowicach została uprzednio przemianowana na ul. Semaforową Uchwałą nr 4/56 Miejskiej Rady Narodowej z dnia 23 stycznia 1956 r.

70 Ul. Stalina w Zakrzowie została uprzednio przemianowana na ul. Warszawską Uchwałą nr 4/56 Miejskiej Rady Narodowej z dnia 23 stycznia 1956 r.

71 Ul. Włodkowica w Oporowie została uprzednio przemianowana na ul. Maksyma Gorkego Uchwałą nr 4/56 Miejskiej Rady Narodowej z dnia 23 stycznia 1956 r. 


\begin{tabular}{|c|l|l|l|}
\hline 17 & Oleśnicka & Zakrzów & Odolanowska \\
\hline 18 & Owczarska & Sołtysowice & Redycka \\
\hline 19 & Piastowska & Muchobór & Nowej Huty \\
\hline 20 & Piekarska & Wojszyce & Chlebowa \\
\hline 21 & Skarbka & miasto Wrocław & Juliana Tuwima \\
\hline 22 & Słoneczna & Wojszyce & Kosmiczna \\
\hline 23 & Spokojna & Bieńkowice & Marsowa \\
\hline 24 & Trentowskiego & Klecina & Buraczana \\
\hline 25 & Żeromskiego & Zakrzów & Przedwiośnie \\
\hline 26 & Górnicza & Zgorzelisko & Malborska \\
\hline 27 & Stanki & Klecina & Łysogórska \\
\hline 28 & Wilczycka & Wojnów & Narciarska \\
\hline 29 & Wileńska & Zgorzelisko & Witebska \\
\hline 30 & Bieruta & Zakrzów & Zatorka \\
\hline 31 & pl. Karola Marksa & Zakrzów & pl. Niepodległości \\
\hline 32 & Karola Marksa & Klecina & Krajowej Rady Narodowej \\
\hline
\end{tabular}

Źródło: opracowanie własne na podstawie analizy treści uchwały nr 4/56.

Następnym aktem prawnym, w którym widoczne są zmagania wrocławskich radnych z kwestią powtarzającego się nazewnictwa, jest Uchwała nr 33/59 Rady Narodowej miasta Wrocławia ${ }^{72} \mathrm{z}$ dnia 30 grudnia 1959 r. Jako podstawę prawna zmian uchwała wskazuje art. 3 i art. 26 Ustawy z dnia 25 stycznia 1958 r. o radach narodowych.

Uchwała zmieniła w sumie 15 nazw ulic, z czego $14 \mathrm{w}$ wyniku przemianowania nazw powtarzających się. Wykonanie uchwały powierzono $\mathrm{w} \S 7$ prezydiom dzielnicowych rad narodowych, zaś w $\S 8$ ustalono, że wchodzi ona w życie z dniem 1 stycznia $1960 \mathrm{r}$.

72 Radę Narodową miasta Wrocławia powołuje się na miejsce Miejskiej Rady Narodowej zgodnie z Ustawą z dnia 20 marca 1950 r. o terenowych organach jednolitej władzy państwowej. Jest ona sukcesorem prawnym Miejskiej Rady Narodowej. Organem zarządzającym i wykonawczym jest Prezydium. Rada Narodowa istnieje do roku 1973, tj. do wejścia w życie Ustawy z 22 listopada o zmianie Konstytucji PRL. 
Tabela 5. Nazwy ulic zmienione Uchwałą nr 26/56 Miejskiej Rady Narodowej z dnia 23 listopada 1956 r. z powodu konieczności usunięcia powtarzającego się nazewnictwa

\begin{tabular}{|c|c|c|c|}
\hline L.p. & Nazwa przed zmianą & Położenie ulicy & Nazwa po zmianie \\
\hline 1 & Wolności & Brochów & Chińska ${ }^{73}$ \\
\hline 2 & 1-go Maja & Brochów & Koreańska \\
\hline 3 & pl. Wolności & Brochów & pl. Mongolski \\
\hline 4 & Matejki & Brochów & Japońska \\
\hline 5 & Rejtana & Brochów & Wietnamska \\
\hline 6 & Parkowa & Brochów & Indyjska \\
\hline 7 & Powstańców & Brochów & Burmańska $^{74}$ \\
\hline 8 & Młyńska & Brochów & Syjamska \\
\hline 9 & Świdnicka & Klecina & $\begin{array}{l}\text { Czekoladowa } \\
\text { (i Wałbrzyska) }^{75}\end{array}$ \\
\hline 10 & Kostrzyńska & Klecina & Karmelkowa \\
\hline 11 & Pollaka & Klecina & Waflowa \\
\hline 12 & Piastów & Ołtaszyn & Bartłomieja Strachowskiego \\
\hline 13 & Mickiewicza (Benedykta Hertza) & Oporów & Michała Śniegockiego ${ }^{76}$ \\
\hline 14 & Karpacka & Stabłowice & Wełniana \\
\hline
\end{tabular}

Źródło: opracowanie autorki artykułu na podstawie analizy treści Uchwały nr 26/56 Miejskiej Rady Narodowej z dnia 23 listopada 1956 r.

73 Ul. Wolności w Brochowie zmieniono Uchwałą nr 115 Miejskiej Rady Narodowej we Wrocławiu z dnia 22 grudnia 1952 r., włączając do niej ul. Główną i zmieniając obie na nowo powstałą ul. Małgorzaty Fornalskiej.

${ }^{74}$ Nazwa pochodzi od państwa Birma (bezpośrednio po II wojnie światowej funkcjonowała nazwa „Burma”). Tabliczki na ul. Birmańską zmieniono w późniejszym czasie, prawdopodobnie bez uchwały.

75 Podzielono ul. Świdnicką na dwie, nadając im nazwy ul. Czekoladowa i ul. Wałbrzyska. W uchwale wskazuje się jednak jedynie przemianowanie na ul. Czekoladową. Prawdopodobnie jest to przeoczenie w maszynopisie, ponieważ kartograficznie zmiana została oznaczona prawidłowo.

76 Ul. Mickiewicza w Oporowie zmieniono na ul. Benedykta Hertza Uchwałą nr 115 Miejskiej Rady Narodowej we Wrocławiu z dnia 22 grudnia 1952 r. O zmianie tej najwyraźniej zapomniano, gdyż dokonuje się ponownej zmiany nazwy ul. Mickiewicza tym razem na ul. Michała Śniegockiego. 


\subsection{Zmiany nazewnictwa ulic w efekcie rozwoju terytorialnego Wrocławia w 1970 roku}

Rozporządzenie Rady Ministrów z dnia 31 marca 1970 r. w sprawie zmiany granic miasta Wrocławia i powiatu trzebnickiego w województwie wrocławskim włączyło wieś Pawłowice do granic miasta Wrocławia z gromady Łozina w powiecie trzebnickim. Po raz kolejny zwiększył się obszar miasta, po raz kolejny także zdublowało się nazewnictwo ulic. Radni podjęli tym razem tylko jedną uchwałę, której celem było zlikwidowanie problemu powtarzającego się nazewnictwa.

Uchwała nr XVIII/90/72 Rady Narodowej miasta Wrocławia z dnia 20 października 1972 r. w sprawie ustalenia nazw niektórych ulic miasta Wrocławia ${ }^{77}$ jako podstawę prawną przeprowadzonych zmian podaje art. $3 \mathrm{i}$ art. 27 Ustawy z dnia 25 stycznia 1958 r. o radach narodowych oraz Zarządzenie Ministra Gospodarki Komunalnej z dnia 28 czerwca 1968 r. w sprawie nadania nazw ulicom i placom oraz numeracji nieruchomości. Treść tej uchwały jest już nieco bardziej zaawansowana $\mathrm{z}$ legislacyjnego punktu widzenia, gdyż wyodrębnia w swej treści części poświęcone zmianom przeprowadzonym na terenie przyłączonej wsi Pawłowice, następnie wskazuje, jakie ulice zmieniono na terenie miasta Wrocławia, oraz odrębnie nadaje nazwy ulicom wcześniej nienazwanym.

Tabela 6. Nazwy ulic zmienione Uchwałą nr XVIII/90/72 Rady Narodowej miasta Wrocławia z dnia 20 października 1972 r. z powodu konieczności usunięcia powtarzającego się nazewnictwa

\begin{tabular}{|c|l|l|}
\hline L.p. & \multicolumn{1}{|c|}{ Nazwa przed zmianą } & \multicolumn{1}{c|}{ Nazwa po zmianie } \\
\hline 1 & Willowa i część Październikowej & Pawłowicka \\
\hline 2 & pozostała część Październikowej & Azaliowa \\
\hline 3 & Bieruta & włączono do istniejącej ul. Przedwiośnie \\
\hline 4 & $\begin{array}{l}\text { od ul. Październikowej w kierunku } \\
\text { północno-wschodnim }\end{array}$ & Przebiśniegowa \\
\hline 5 & Krótka & Ruciana \\
\hline 6 & Wiejska & Daliowa \\
\hline 7 & Dębowa & Starodębowa \\
\hline 8 & Kolejowa & Bratkowa \\
\hline 9 & Tysiąclecia & Złocieniowa \\
\hline
\end{tabular}

77 Treścią uchwały dysponuję dzięki uprzejmości prof. dr. hab. T. Kruszewskiego (zbiory prywatne). Jej oryginał znajduje się w Archiwum Państwowym we Wrocławiu. 


\begin{tabular}{|c|l|l|}
\hline 10 & Brzozowa & Barwinkowa \\
\hline 11 & $\begin{array}{l}\text { od ul. Bieruta w kierunku północno- } \\
\text { wschodnim }\end{array}$ & Bławatkowa \\
\hline 12 & Odrodzenia Polski & Mirtowa \\
\hline 13 & Lipowa (i Plonowa) & Malwowa $^{78}$ \\
\hline 14 & od ul. Lipowej w kierunku toru PKP & Liliowa \\
\hline 15 & od ul. Ogrodowej do ul. Lipowej (Miła) & Szarotkowa \\
\hline 16 & Spokojna & Stokrotkowa \\
\hline 17 & Głucha & Mieczykowa \\
\hline 18 & Ogrodowa & Sasankowa \\
\hline 19 & Jeziorna & Jeziorowa \\
\hline 20 & Parkowa & Krokusowa \\
\hline
\end{tabular}

Źródło: opracowanie własne na podstawie analizy treści Uchwały nr XVIII/90/72 Rady Narodowej miasta Wrocławia z dnia 20 października 1972 r.

Uchwała zmieniła w sumie 24 nazwy ulic oraz nadała nazwę 8 ulicom uprzednio nazwy niemającym. W samych Pawłowicach zmieniono w sumie 20 nazw ulic, z czego z powodu zdublowania nazw po przyłączeniu Pawłowic do Wrocławia - 15. W tabeli ujęłam jednak wszystkie zmienione w Pawłowicach nazwy, by pokazać, że przyłączenie nowych terenów czasami wymuszało nazwanie wcześniej nienazwanej drogi lub też stwarzało konieczność podziału ulicy i nadania nazwy jej nowo wyodrębnionej części. Zmiany te radni przeprowadzali już ściśle w oparciu o mapę, która stanowi integralną część uchwały. Ponadto do uchwały załączone jest uzasadnienie, w którym wskazano na konieczność sprostania wymogom określonym w Zarządzeniu Ministra Gospodarki Komunalnej z dnia 28 czerwca 1968 r. oraz zasadom przyjętym dla miasta Wrocławia. Zgodnie z uzasadnieniem zmiany były konieczne, gdyż powtarzały się nazwy ulic już istniejących w mieście, a ponadto nazwy nie miały jednolitego charakteru nazewniczego. Komisja Nazewnictwa Ulic przy Towarzystwie Miłośników Wrocławia opracowała propozycje nazw ulic od nazw kwiatów, które przyjęto w dniu 24 lutego $1971 \mathrm{r}$. na wspólnym zebraniu z mieszkańcami osiedla i przedstawicielami Prezydium Dzielnicowej Rady Narodowej ${ }^{80}$.

78 W uchwale wskazuje się jedynie zmianę ul. Lipowej na ul. Malwową, ale kartograficznie zmiana obejmuje ul. Lipową oraz ul. Plonową. Mapa stanowi integralną część uchwały.

${ }^{79} \mathrm{~W}$ uchwale wskazuje się odcinek od ul. Ogrodowej do ul. Lipowej, jednak z analizy mapy wynika, że była to już nazwana ul. Miła.

80 Uzasadnienie do Uchwały nr XVIII/90/72 Rady Narodowej miasta Wrocławia z dnia 20 października 1972 r. w sprawie ustalenia nazw niektórych ulic miasta Wrocławia. 


\subsection{Zmiany nazewnictwa ulic w efekcie rozwoju terytorialnego Wrocławia w 1973 roku}

W dniu 1 stycznia 1973 r. Rozporządzeniem Rady Ministrów z dnia 30 listopada 1972 r. w sprawie zmiany granic miast Krakowa, Poznania i Wrocławia do miasta przyłączono aż 13 podwrocławskich wsi: Jarnołtów, Jerzmanowo, Kłokoczyce, Lipę Piotrowską, Marszowice, Mokrą, Osiniec, Polanowice, Rędzin, Strachowice, Świniary, Widawę, Żar. Ponownie zrodziła się potrzeba przemianowania części ulic oraz nazwania dróg bezimiennych. Po długotrwałych konsultacjach społecznych z mieszkańcami przyłączonych osiedli radni podjęli Uchwałę nr VI/28/74 Rady Narodowej miasta Wrocławia z dnia 20 grudnia 1974 r. w sprawie ustalenia nazw ulic w mieście Wrocławiu ${ }^{81}$. Jako podstawę prawną zmian podaje się art. 20 ust. 2 pkt 7 Ustawy z dnia 25 stycznia 1958 r. o radach narodowych (tekst jednolity) $^{82}$.

Tabela 7. Nazwy ulic zmienione Uchwałą nr VI/28/74 Rady Narodowej miasta Wrocławia z dnia

20 grudnia 1974 r. z powodu konieczności usunięcia powtarzającego się nazewnictwa

\begin{tabular}{|r|l|l|l|} 
L.p. & \multicolumn{1}{|c|}{$\begin{array}{c}\text { Nazwa przed } \\
\text { zmianą }\end{array}$} & Położenie ulicy & \multicolumn{2}{c|}{ Nazwa po zmianie } \\
\hline 1 & Chłopska & Polanowice & Starościńska \\
\hline 2 & 1 -go Maja & Rędzin & podzielono na ul. Kajakarzy i ul. Wędkarzy \\
\hline 3 & Odrzańska & Rędzin & podzielono na ul. Piłkarzy i ul. Siatkarzy \\
\hline 4 & Łąkowa & Rędzin & Łyżwiarzy \\
\hline 5 & Robotnicza & Rędzin & Hokeistów \\
\hline 6 & Kolejowa & Widawa & Miętowa ${ }^{83}$ \\
\hline 7 & Polna & Widawa & Ostowa ${ }^{84}$ \\
\hline 8 & Obornicka & Lipa Piotrowska & Pełczyńska \\
\hline 9 & Wrocławska & Widawa & Cholewkarska \\
\hline 10 & Szkolna & Widawa & Dekarska \\
\hline
\end{tabular}

81 Treścią uchwały dysponuję dzięki uprzejmości prof. dr. hab. Tomasza Kruszewskiego (zbiory prywatne). Jej oryginał znajduje się w Archiwum Państwowym we Wrocławiu.

82 Dz.U. z 1973 r. Nr 47, poz. 277.

${ }^{83} \mathrm{~W}$ uchwale określa się położenie ul. Miętowej w osiedlu Lipa Piotrowska, a powinno być w osiedlu Widawa. Błąd wynika prawdopodobnie z bezpośredniego sąsiedztwa przyłączonych osiedli.

${ }^{84}$ W uchwale określa się położenie ul. Ostowej w osiedlu Lipa Piotrowska, a powinno być w osiedlu Widawa. Błąd wynika prawdopodobnie z bezpośredniego sąsiedztwa przyłączonych osiedli. 


\begin{tabular}{|c|c|c|c|}
\hline 11 & pl. Słoneczny & Widawa & Dekarska \\
\hline 12 & Młyńska & Widawa & Fryzjerska \\
\hline 13 & Polna & Widawa & Grawerska, Jubilerska, Strażacka ${ }^{85}$ \\
\hline 14 & Kościuszki & Widawa & Księgarska \\
\hline 15 & Klasztorowa & Widawa & Kaletnicza \\
\hline 16 & Daszyńskiego & Widawa & Kominiarska \\
\hline 17 & Fortowa & Widawa & Meliorancka \\
\hline 18 & Robotnicza & Widawa & Pielęgniarska \\
\hline 19 & Kościelna & Widawa & Zduńska \\
\hline 20 & Wrocławska & Widawa & Sułowska \\
\hline 21 & Obornicka & Świniary & podzielono na ul. Pęgowską i ul. Zarzecze \\
\hline 22 & Damska & Świniary & Zagaje \\
\hline 23 & Obornicka & Świniary & Zaziębie \\
\hline 24 & Kolejowa & Świniary & podzielono na ul. Zabłocie i ul. Dalimira \\
\hline 25 & Parkowa & Świniary & Mikory \\
\hline 26 & Wrocławska & Świniary & Zajączkowska \\
\hline 27 & Polna & Mokra & Smolna \\
\hline 28 & Pszczelna & Mokra & Ulowa \\
\hline 29 & Leśna & Mokra & Chobieńska \\
\hline 30 & Zamkowa & Mokra & Watowa \\
\hline 31 & Brzezińska & Mokra & Wińska \\
\hline 32 & Łąkowa & Mokra & Mojęcicka \\
\hline 33 & Sosnowa & Mokra & Junacka $^{86}$ \\
\hline 34 & Kolonijna & Marszowice & $\begin{array}{l}\text { podzielono na ul. Łososiowicką } \\
\text { i ul. Wilkszyńską }\end{array}$ \\
\hline 35 & Owczarska & Marszowice & Gwizdanowska \\
\hline 36 & Boczna & Marszowice & Małomicka \\
\hline 37 & Bonanzy & Marszowice & Bojanowska \\
\hline 38 & Leśnicka & Marszowice & Marszowicka \\
\hline
\end{tabular}

85 W osiedlu Widawa dwukrotne przemianowanie ul. Polnej oznacza, że podzielono ją na odcinki, nadając nowe nazwy, odpowiednio ul. Grawerska, ul. Jubilerska i ul. Strażacka. ficznej.

${ }^{86}$ Całkowicie pominięto tę zmianę w treści uchwały, jednak wynika ona $\mathrm{z}$ analizy kartogra- 


\begin{tabular}{|c|l|l|l|}
\hline 39 & Zamkowa & Jarnołtów & Jarnołtowska \\
\hline 40 & Kątecka & Jarnołtów & Samotworska \\
\hline 41 & Ogrodowa & Jarnołtów & Gruszowa \\
\hline 42 & Łąkowa & Jarnołtów & Gałowska \\
\hline 43 & Polna & Jerzmanowo & Gałowska ${ }^{87}$ \\
\hline 44 & Główna & Jerzmanowo & Jerzmanowska \\
\hline 45 & Kościelna & Jerzmanowo & Anny Jasińskiej \\
\hline 46 & Uniejska & Jerzmanowo & Heleny i Ludwika Adamczewskich \\
\hline 47 & Fabryczna & Jerzmanowo & Augustyna Kośnego \\
\hline 48 & Główna & Osiniec & Osiniecka \\
\hline 49 & Jerzmanowska & $\begin{array}{l}\text { Osiniec, } \\
\text { Strachowice }\end{array}$ & $\begin{array}{l}\text { podzielono na ul. Osiniecką } \\
\text { i ul. Rdestową }\end{array}$ \\
\hline 50 & Łąkowa & Strachowice & Widłakowa \\
\hline 51 & Ogrodowa & Strachowice & $\begin{array}{l}\text { podzielono na ul. Stanisława Skarżyńskiego } \\
\text { i ul. Desantową }\end{array}$ \\
\hline 52 & pl. Słoneczny & Strachowice & Władysława i Jana Wardzyńskich \\
\hline 53 & Główna & Strachowice & Władysława Zarembowicza \\
\hline 54 & Lipowa & Strachowice & Władysława Zarembowicza ${ }^{89}$ \\
\hline
\end{tabular}

Źródło: Opracowanie własne na podstawie analizy treści Uchwały nr XVIII/90/72 Rady Narodowej miasta Wrocławia z dnia 20 października $1972 \mathrm{r}$.

W uzasadnieniu zmian podaje się, że nazwy ulic w osiedlach przyłączonych do miasta nie odpowiadały wymogom określonym w Zarządzeniu Ministra Gospodarki Komunalnej z dnia 28 czerwca 1968 r. oraz zasadom przyjętym dla miasta Wrocławia. Wskazuje się, że wiele ulic miało nazwy już w mieście istniejące. Uchwała zmienia bądź nadaje nowym drogom w sumie aż 120 nazw. W wyniku usuwania nazw dublujących się zmienionych zostało około 54 nazw. Trudnością legislacyjna, jaką musiałam przezwyciężyć, dokonując analizy powyższej uchwały, jest brak podawania nazwy ulicy, która została zmieniona. Podaje się jedynie nową nazwę. Postąpiono tak, ponieważ integralną częścią uchwały są mapy wcielanych do miasta osiedli i to na nich nanosi się propozycje zmian. Powyższe zestawienie tabelaryczne przedstawia więc zmiany w oparciu o analizę map, ale przede wszystkim o zapiski i informacje ustne przekazane mi przez prof. dr. hab. T. Kruszewskiego.

87 Bezpośrednie sąsiedztwo wcielonych do Wrocławia wsi Jarnołtów i Jerzmanowo jest powodem połączenia w jedną ul. Gałowską dwóch ulic, z których każda funkcjonowała przed zmianą w osobnej wsi - ul. Łąkowa w Jarnołtowie, a ul. Polna w Jerzmanowie. Nie jest to więc nieumyślne zdublowanie nazwy ul. Gałowskiej, lecz połączenie dwóch ulic w jedną. 
Zapewne po wejściu w życie powyższej uchwały sądzono, iż problem podwójnego nazewnictwa w mieście Wrocław został rozwiązany. Okazuje się jednak, że we Wrocławiu funkcjonowały jeszcze dwie ulice Polne oraz dwie ulice Krótkie aż do 1993 r. Prawdopodobnie sygnały ze strony społeczeństwa, tj. zwyczajnie niemożność trafienia pod właściwy adres, stały się przyczyną zmiany przeprowadzonej Uchwałą nr LXXI/455/93 Rady Miejskiej Wrocławia z dnia 9 października 1993 r. w sprawie ustalenia nazw ulic na terenie Wrocławia ${ }^{88}$.

Tabela 8. Nazwy ulic zmienione Uchwałą nr LXXI/455/93 Rady Miejskiej Wrocławia z dnia 9 października 1993 r. w sprawie ustalenia nazw ulic na terenie Wrocławia z powodu konieczności usunięcia powtarzającego się nazewnictwa

\begin{tabular}{|c|l|l|l|}
\hline L.p. & Nazwa przed zmianą & Położenie ulicy & Nazwa po zmianie \\
\hline 1 & Polna & miasto Wrocław (Złotniki) & Mieroszowska $^{91}$ \\
\hline 2 & Krótka & miasto Wrocław (Osobowice) & Edmonda Micheleta $^{92}$ \\
\hline
\end{tabular}

Źródło: opracowanie autorki artykułu na podstawie analizy treści Uchwały nr LXXI/455/93 Rady Miejskiej Wrocławia z dnia 9 października 1993 r. w sprawie ustalenia nazw ulic na terenie Wrocławia.

Uchwała zmienia w sumie cztery nazwy ulic, z czego dwie z powodu ich dublowania się. Nie są mi znane okoliczności, jakie zdecydowały o wyborze, którą $\mathrm{z}$ dublujących się ulic należy zmienić. $Z$ dużym prawdopodobieństwem mogę jednak stwierdzić, że kierowano się względami ekonomicznymi.

\section{Podsumowanie}

Przyłączanie do miasta podmiejskich wsi każdorazowo odznaczało rewolucję w nazewnictwie ulic. Granice miasta Wrocławia trzykrotnie rozszerzyły się po II wojnie światowej. $Z$ analizy powyższych aktów prawnych wynika, że powiększanie się granic Wrocławia o nowe osiedla spowodowało konieczność zmiany aż 232 nazw ulic z powodu ich powtarzania się. Liczbę tę należy jednak traktować orientacyjnie, choć z dużą dozą prawdopodobieństwa. Pierwsze uchwały zawierają bowiem błędy zarówno ortograficzne, jak i rzeczowe. Niektóre z nazw przez niedopatrzenie przemianowuje się kilkakrotnie, inne pozostawia bez zmiany na długie lata i dopiero czynnik społeczny weryfikuje sens przeprowadzonych zmian lub zauważa konieczność przeprowadzenia zmiany w ogóle. Początkowo uchwały nie zawierały także uzasadnień przeprowadzanych zmian, ani tym bardziej nie wyposaża się ich

88 B.U. RMW z 15.10 .1993 r. Nr 11, poz. 102.

89 Zdecydowano o pozostawieniu ul. Polnej na Brochowie, co wynika z załączonej do uchwały mapy.

90 Zdecydowano o pozostawieniu ul. Krótkiej na Brochowie, co wynika z załączonej do uchwały mapy. 
w mapy. Natomiast te uchwały, których integralną częścią jest mapa, również nie są wolne od błędów kartograficznych. Materię nazewnictwa badałam z całą starannością jednak zdaję sobie sprawę, że nie trudno o błędne odczytanie maszynopisu czy też wreszcie o zwykłe przeoczenie. Najistotniejsze jest jednak pokazanie sposobu, w jaki dokonywano poszczególnych zmian, oraz dostrzeżenie jego ewolucji. Dopiero z perspektywy czasu możliwa jest próba oceny, czy akt normatywny, jakim jest podjęta uchwała, zrealizował cele, które radni obierali przy jego tworzeniu.

Poczatkowo zmiany nazewnictwa chciałam przedstawić alfabetycznie, lecz ostatecznie zdecydowałam, że w tabelach zachowam kolejność zmian, jaką podaja uchwały. Pozwoliło to pokazać zmiany techniki prawodawczej, jaką przyjmowali radni, opracowując treści uchwał przemianowujących nazwy powtarzające się. W uchwałach z lat 50. XX w. daje się zauważyć przypadkowa kolejność zmienianych ulic, z czasem sposób ułożenia nazewnictwa w uchwale ulega ewolucji i przybiera alfabetyczną formę. W latach 70 . XX w. natomiast nazewnictwo w uchwałach porządkowane jest z podziałem na poszczególne osiedla przyłączone do miasta.

Umiejscawiając pozornie „techniczne” zmiany w kontekście historycznym, można dojść do wniosku, że uchwałami z lat 50. XX w. wcale nie rządzi przypadkowość, lecz ideologie. Radni przemianowują nazewnictwo samowolnie, powołując komisje spośród samych siebie. Patronów narodowych zastępowano w nazewnictwie działaczami robotniczymi, rosyjskimi pisarzami. Często ważniejsze ideologicznie zmiany były przeprowadzane jako pierwsze, jako pierwsze wchodziły także w życie. W okresie stabilizacji po roku 1956 nazewnictwo nadal związane było z ustrojem socjalizmu, jednak nie ma już w mieście ulicy Stalina. Rozwój terytorialny miasta sprzyjał upolitycznieniu wielu nazw ulic. Kolejne zmiany terytorialne w granicach miasta Wrocławia w roku 1970 i 1973 zwykle nie były już tak chaotyczne. Przeprowadzano je zarówno w porozumieniu ze społeczeństwem, jak i pod okiem fachowców skupionych w Komisji Nazewnictwa Ulic Towarzystwa Miłośników Wrocławia. Przemianowanie nazw wskutek włączania nowych osiedli dokonywało się tematycznie i całościowo.

Jeśli chodzi o tryb prawny przeprowadzanych zmian, w zasadzie nie uległ on zmianie. Każdorazowo zmiany nazewnictwa w analizowanym przeze mnie okresie dokonywano uchwała. W wyniku zmiany ustawodawstwa na szczeblu centralnym zmieniło się jedynie określenie organów mających legitymacje do przeprowadzania zmian, mianowicie w latach 1946-1990 są to poszczególne rady narodowe funkcjonujące we Wrocławiu, a następnie od roku 1990 do dziś Rada Miejska Wrocławia.

Nazewnictwo wrocławskich ulic długo nie mogło uwolnić się od rzeczowych błędów. Wiele ulic zmieniano kilkakrotnie, pomijając zmianę dokonaną uprzednio $^{91}$. Zanim dokonano reasumpcji danej nazwy, mijały kolejne lata. Należy za-

91 Działo się tak w przypadku przemianowania ul. Kościuszki czy też ul. Mickiewicza w Ołtaszynie. 
stanowić się, co jest przyczyną tego stanu. Pojawia się wątpliwość, czy jest to problem z wykonaniem uchwały w terenie, czy też może niedopatrzenie radnych. Nie w każdym przypadku można tę kwestię rozstrzygnąc jednoznacznie. Wówczas również nasuwa się pytanie o sens przeprowadzania zmian w nazewnictwie z powodu przyłączania nowych terenów do miasta. Nie tylko we Wrocławiu, lecz także w innych miastach Polski istnieje tendencja do przemianowywania nazw powtarzających się. W wielu krajach Europy przyjęto zgoła inne, bardziej ekonomiczne rozwiązania. Na przykład we Francji stosuje się podział miast na okręgi, Paryż dzieli się na 20 okręgów, tzw. arrondissements. W Niemczech natomiast funkcjonuje bardzo sprawnie rozbudowany system kodów pocztowych. Kod pocztowy jest czymś więcej niż tylko numerem adresowym, jest bowiem nieodłącznym elementem adresu. W Polsce kod pocztowy, czyli pocztowy numer adresowy, został stworzony na potrzeby ułatwienia segregacji przesyłek. Nie ma więc wypracowanej tradycji posługiwania się kodem pocztowym w celu określenia miejsca zamieszkania. Góruje jednak tendencja posługiwania się nazwą i numerem ulicy. Nazwa ulicy jest traktowana przez społeczeństwo w Polsce sentymentalnie i choć niejednokrotnie jej zmiana okazuje się zarówno kosztowna, jak i utrudniająca funkcjonowanie - przynajmniej w początkowym okresie po zmianie - to mimo wszystko zostaje przeprowadzona. Nazewnictwo ulic jest bowiem problematyką wrażliwą na przemiany historyczne, społeczne oraz gospodarcze, ciągle aktualną i nieustannie budzącą kontrowersje.

\section{Bibliografia}

\section{Wykaz aktów prawnych}

Dekret Naczelnego Dowódcy Józefa Piłsudskiego z 14 listopada 1918 r. (Dz.P.P.P. z 1918 r. Nr 17, poz. 40).

Dekret z 22 listopada 1918 r. o najwyższej władzy reprezentacyjnej Republiki Polskiej (Dz.P.P.P. z 1918 r. Nr 17, poz. 41).

Dekret Polskiego Komitetu Wyzwolenia Narodowego z dnia 21 sierpnia 1944 r. o trybie powołania władz administracji ogólnej I-ej i II-ej instancji (Dz.U. z 1944 r. Nr 2, poz. 8).

Dekret Polskiego Komitetu Wyzwolenia Narodowego z dnia 23 listopada 1944 r. o organizacji i zakresie działania samorządu terytorialnego (Dz.U. z 1944 r. Nr 14, poz. 74.).

Rozporządzenie Ministra Gospodarki Komunalnej z dnia 25 czerwca 1968 r. w sprawie numeracji nieruchomości (Dz.U. z 1968 r. Nr 23, poz. 151).

Rozporządzenie Prezydenta Rzeczpospolitej z dnia 24 października 1934 r. o ustalaniu nazw miejscowości i numeracji nieruchomości (Dz.U. z 1934 r. Nr 94, poz. 850, następnie Dz.U. z 1948 r. Nr 36, poz. 251).

Rozporządzenie Rady Ministrów z dnia 14 grudnia 1950 r. w sprawie zmiany granic miast Wałbrzycha i Wrocławia włączające do granic miasta Wrocławia obręby katastralne (Dz.U. z 1950 r. Nr 57, poz. 509). 
Rozporządzenie Rady Ministrów z dnia 31 marca 1970 r. w sprawie zmiany granic miasta Wrocławia i powiatu trzebnickiego w województwie wrocławskim (Dz.U. z 1970 r. Nr 8, poz. 70).

Rozporządzenie Rady Ministrów z dnia 30 listopada 1972 r. w sprawie zmiany granic miast Krakowa, Poznania i Wrocławia (Dz.U. z 1972 r. Nr 50, poz. 323).

Uchwała nr 102 Miejskiej Rady Narodowej z dnia 22 listopada 1952 r. (zbiory prywatne prof. dr. hab. Tomasza Kruszewskiego).

Uchwała nr 115 Miejskiej Rady Narodowej z dnia 22 grudnia 1952 r. (zbiory prywatne prof. dr hab. Tomasza Kruszewskiego).

Uchwała nr 4/56 Miejskiej Rady Narodowej z dnia 23 stycznia 1956 r. (zbiory prywatne prof. dr. hab. Tomasza Kruszewskiego).

Uchwała nr 26/56 Miejskiej Rady Narodowej z dnia 23 listopada 1956 r. (zbiory prywatne prof. dr. hab. Tomasza Kruszewskiego).

Uchwała nr 33/59 Rady Narodowej Miasta Wrocławia z dnia 30 grudnia 1959 r. (zbiory prywatne prof. dr. hab. Tomasza Kruszewskiego).

Uchwała nr XVIII/90/72 Rady Narodowej miasta Wrocławia z dnia 20 października 1972 r. w sprawie ustalenia nazw niektórych ulic miasta Wrocławia (zbiory prywatne prof. dr. hab. Tomasza Kruszewskiego).

Uchwała nr VI/28/74 Rady Narodowej miasta Wrocławia z dnia 20 grudnia 1974 r. w sprawie ustalenia nazw ulic w mieście Wrocławiu (zbiory prywatne prof. dra hab. Tomasza Kruszewskiego).

Uchwała nr LXXI/455/93 Rady Miejskiej Wrocławia z dnia 9 października 1993 r. w sprawie ustalenia nazw ulic na terenie Wrocławia (B.U. RMW z 15.10.1993 r. Nr 11, poz.102.)

Ustawa z dnia 10 grudnia 1920 r. o budowie i utrzymaniu dróg publicznych w Rzeczypospolitej Polskiej (Dz.U. z 1921 r. Nr 6, poz. 32).

Ustawa z dnia 23 marca 1933 r. o częściowej zmianie ustroju samorządu terytorialnego (Dz.U. z 1933 r. Nr 35, poz. 294).

Ustawa z dnia 11 września 1944 r. o organizacji i zakresie działania rad narodowych (Dz.U. z 1944 r. Nr 5, poz. 22, następnie Dz.U. z 1944 r. Nr 19, poz. 98, następnie Dz.U. z 1945 r. Nr 17, poz. 93, następnie Dz.U. z 1946 r. Nr 3, poz. 19 i 26).

Ustawa z dnia 20 marca 1950 r. o terenowych organach jednolitej władzy państwowej (Dz.U. z 1950 r., Nr 14, poz. 130).

Ustawa z dnia 25 stycznia 1958 r. o radach narodowych (Dz.U. z 1958 r. Nr 29, poz. 172, następnie Dz.U. z 1973 r. Nr 47, poz. 277, tekst jednolity).

Zarządzenie Ministra Gospodarki Komunalnej z dnia 28 czerwca 1968 r. o ustaleniu wytycznych w sprawie nadawania nazw ulicom i placom oraz numeracji nieruchomości (M.P. z 1968 r. Nr 30, poz. 197).

\section{Wykaz źródeł archiwalnych}

Archiwum Państwowe we Wrocławiu Oddział w Legnicy, Zarząd Miejski w Złotoryi 45/50, sygn. 1, k. 24.

Archiwum Państwowe we Wrocławiu, Prezydium Rady Narodowej miasta Wrocławia, 1, Protokół VI sesji Miejskiej Rady Narodowej we Wrocławiu, 21 grudnia 1950 r., k. 205.

Archiwum Państwowe we Wrocławiu, Prezydium Rady Narodowej miasta Wrocławia, 331, Protokół nr 1 posiedzenia Niestałej Komisji Nazewnictwa Ulic, 25 stycznia 1951 r., k. 1.

Protokół I pos. plen. Krajowej Rady Narodowej str. 30-36, [w:] A. Gwiżdż, J. Zakrzewska, Konstytucja i podstawowe akty ustawodawcze Polskiej Rzeczypospolitej Ludowej, Warszawa 1958, s. 53-59.

Prawo 321, 2016

(C) for this edition by CNS 


\section{Literatura}

Antkowiak Z., Patroni ulic Wrocławia, Wrocław 1982.

Antkowiak Z., Ulice i place Wrocławia, Wrocław-Warszawa-Kraków 1970.

Antkowiak Z., Wrocław od A do Z, Wrocław-Warszawa-Kraków, wyd. 1. 1991 i wyd. 2. 1997.

Encyklopedia Wrocławia, red. J. Harasimowicz, W. Suleja, Wrocław 2006.

Grünhagen C., Regesten zur Schleisischen Geschichte, Josef Max \& COMP., Wrocław 1866.

Jancewicz B., Zmiany nazw wrocławskich ulic w 1989 roku, „Kalendarz Wrocławski”, Wrocław 1991, s. $86-87$.

Jancewicz B., Zmiany nazw wrocławskich ulic w 1990 roku, „Kalendarz Wrocławski”, Wrocław 1992, s. 35-37.

Jancewicz B., Zmiany nazw wrocławskich ulic w 1991 roku, „Kalendarz Wrocławski”, Wrocław 1993, s. 61-63.

Jancewicz B., Zmiany nazw wrocławskich ulic w 1992 roku, „Kalendarz Wrocławski”, Wrocław 1994, s. 66-68.

Jancewicz B., Zmiany nazw wrocławskich ulic w 1993 roku, „Kalendarz Wrocławski”, Wrocław 1995, s. 88-90.

Jancewicz B., Nowe nazwy ulic we Wrocławiu w 1994 roku, „Kalendarz Wrocławski”, Wrocław 1996, s. 107-112.

Jancewicz B., Nowe nazwy ulic we Wrocławiu w 1995 roku, „Kalendarz Wrocławski”, Wrocław 1997, s. 192-198.

Jancewicz B., Nowe nazwy ulic we Wrocławiu w 1996 roku, „Kalendarz Wrocławski”, Wrocław 1998, s. 175-178.

Jancewicz B., Nowe nazwy ulic we Wrocławiu w 1997 roku, „Kalendarz Wrocławski”, Wrocław 1999, s. 170-173.

Jankowska M., Administracyjno-prawna problematyka zmiany nazewnictwa ulic Wroctawia w latach 1945-1946, „Folia Iuridica Wratislaviensis” 2, 2013, 1.

Jochelson A., Jak powstawały polskie nazwy ulic i dzielnic w odzyskanym Wrocławiu, „Kalendarz Wrocławski”, Wrocław 1968, s. 228-232.

Jochelson A., Ulica Kazimierza Wielkiego, „Kalendarz Wrocławski”, Wrocław 1985, s. 303- 311.

Kędziora K., Nazewnictwo ulic Wrocławia w latach 1945-1994, Warszawa 2012.

Kobel E., Patroni wrocławskich ulic, placów i zaułków, Wrocław 2008.

Kruszewski T., Niemiecko-polski spis ulic, placów i mostów Wrocławia 1873-1997, Wrocław 1997.

Kruszewski T., Prawne aspekty nazewnictwa ulic, [w:] Nazwy ulic Wrocławia, red. B. Jancewicz, L. Smołka, Wrocław 2000, s. 31-34.

Kruszewski T., Rejestry podatkowe z XVI-XVIII w. jako źródło do badań historii nazw ulic we Wrocławiu, „Prawo CCXL. Studia Historycznoprawne”, Wrocław 1994, s. 155-167.

Kruszewski T., Zmiany nazw ulic we Wrocławiu w latach Trzeciej Rzeszy, „Acta Universitatis Wratislaviensis 1860, Studia Nad Faszyzmem i Zbrodniami Hitlerowskimi” XIX, Wrocław 1996, s. 243-270.

Magdziarz Z., Zmiany nazw ulic widziane z drugiej strony, „Kalendarz Wrocławski”, Wrocław 1995, s. 90-91.

Markgraf H., Die Straßen Breslaus, Breslau 1896.

Prawo administracyjne, red. J. Boć, Wrocław 2010.

Scheuermann G., Das Breslau Lexikon, t. I. A-L, t. II. M-Z, Dülmen 1994.

Siciński B., Komisja Nazewnictwa Ulic, „Kalendarz Wrocławski”, Wrocław 1991, s. 86-87.

Weiss A., Wie Breslau wurde, Breslau 1907. 


\title{
Administrative-legal aspects of changes of repeated street names in Wrocław after the Second World War
}

\author{
Summary
}

The author of the article discusses the problem of changes in streets names in Wrockaw introduced as a result of the territorial growth of the city after the Second World War. On each occasion the expansion of the territory of the city following the incorporation of successive neighbourhoods brought with it the need to solve the problem of two, often three or even four streets or squares with the same name in the city. The author has established the legitimacy and the legal basis of the changes. She presents the names themselves in an analytical manner, verifying each changed street name in terms of its linguistic or substantive correctness. In addition, she discusses the legislative path and the legal procedure applied in the introduction of the changes. She also points to the placement of names in the historical and political context, examines their social background and attempts to assess the validity of this type of changes, comparing them with solutions adopted in other countries of Europe.

Keywords: Wrocław street names, changes of Wrocław street names, repeated street names, Wrocław after the Second World War II, legal aspect of changes in street names, territorial growth of Wrocław, Street Name Commission

\section{Verwaltungsrechtliche Aspekte der Änderungen der sich wiederholenden Straßennamen in Breslau nach dem Zweiten Weltkrieg}

\section{Zusammenfassung}

In diesem Artikel wurde die Problematik der Änderungen der Straßennamen in Breslau, die wegen der territorialen Entwicklung der Stadt nach dem Zweiten Weltkrieg durchgeführt wurden, besprochen. Es wurde festgestellt, dass die sukzessive Erweiterung des Stadtbereiches infolge der Angliederung weiterer Siedlungen immer wieder die Notwendigkeit hervorrief, mit den zweifach, mehrmals dreifach und vierfach auftretenden gleichen Bezeichnung von Straßen oder Plätzen zurechtzukommen. Es wurden die Legitimation und die rechtlichen Grundlagen der durchgeführten Änderungen festgestellt. Die Namensgebung wurde analytisch vorgestellt, jeder geänderte Straßenname wurde hinsichtlich seiner sprachlichen und sachlichen Richtigkeit verifiziert. Besprochen wurde auch das Gesetzgebungsverfahren und die gesetzgebende Technik der durchgeführten Änderungen. Schließlich wurde der historische, politische und soziale Hintergrund der Änderungen gezeigt sowie die Grundsätzlichkeit derartiger Änderungen bewertet, die in anderen Ländern Europas vorgenommenen Lösungen danebenhaltend.

Schlüsselworte: Straßennamen Breslaus, Änderungen der Straßennamen Breslaus, sich wiederholende Straßennamen, Breslau nach dem Zweiten Weltkrieg, rechtliche Aspekte der Straßennamenänderungen, territoriale Entwicklung Breslaus, Kommission für Straßennamen. 